\title{
Community-based entrepreneurship: evidences from a retail case study
}

\author{
Sazzad Parwez
}

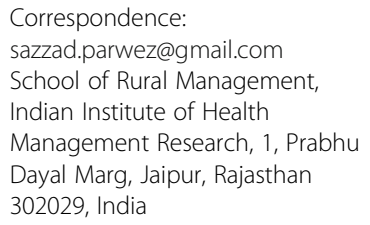

\begin{abstract}
Community-based entrepreneurship is considered to be an important instrument for the realization of potential among marginal and deprived communities isolated from the mainstream economy and is important in bringing social upliftment. Cultural values, shared resources, linkages, and mutual trust work for the community, nurtured through close personal relations for the functioning of economic activities. Entrepreneurial activities creating local public goods for a community have a comparative advantage over the absolute market-oriented activities. This paper tries to follow a case study method to analyze the community-based entrepreneurship in a marginal community (Muslim). Many self-employed Muslim workers and small businesses in urban centers in a non-Islamic society indicate that they bound to have a great propensity for entrepreneurship compared to the indigenous population. The government needs to introduce a policy with implicative measures for financial and technical support to these entrepreneurial activities.
\end{abstract}

Keywords: Community, Entrepreneurship, Friendly Mart, Muslim, Retail

\section{Background}

To alleviate poverty, development agencies and multinational organizations have been greatly involved in interventions in the developing world for many decades. It has been observed that the most widely adopted approaches have often been paternalistic, even if unintentionally, while ignoring the strength of local institutions (Davis 1993). Most of the poverty alleviation programs have degenerated into "charity" rather than building the local and durable self-reliance (Burkey, 1993). It is evident that the real effect of developmental interventions has been compromising in respect to community development and eventually contributes to the creation of real poverty rather than alleviation (Cornwall 1998; Crewe, and Harrison 1998; Sachs 1992).

A major issue in developmental activities is that projects are generally conceived and implemented by agencies rather than by community members. This has often led to a lack of ownership on the part of the local population and beneficiaries. It is exemplified by the fact that once the finances of a project dry out, the interest of the local population also recedes. Identification of this trend has forced several international and domestic agencies to conceive and implement projects with enhanced local participation (Brinkerhoff 1996; World Bank 1996).

To enhance collective development, it has been identified that focus should be on the creation of sustainable economic activities rather than welfare projects (Parwez 2016b). It

(c) The Author(s). 2017 Open Access This article is distributed under the terms of the Creative Commons Attribution 4.0 International License (http://creativecommons.org/licenses/by/4.0/), which permits unrestricted use, distribution, and reproduction in any medium, provided you give appropriate credit to the original author(s) and the source, provide a link to the Creative Commons license, and indicate if changes were made. 
has been commonly acknowledged that enterprise development can be a crucial element in the process of economic development [Drucker 1995; Schumpeter (1934) 1983]. Numerous initiatives that have been taken and executed aimed at promoting entrepreneurship development to improve the socio-economic condition. It is discouraging to observe the general lack of success of the entrepreneurial venture as very few examples are there to be replicated.

These failures suggest that there are many gaps in our understanding of entrepreneurial processes. A recent research and theory on transitional economies, together with growing interest in micro-credits, has an effect on community issues as principal elements of entrepreneurial activity among underprivileged people (Bates 1997; Cornwall 1998; Anderson, and Jack 2002; Parwez 2015). Further, values of the western world emphasize continuation of the conventional view of entrepreneurship (Peterson 1988), and efforts to encourage entrepreneurship in developing countries have been shaped by a western outlook. But societies differ substantially in the degree to which they incorporate elements of entrepreneurship (Hofstede 1980).

Generally, developing or poor countries suffer from adverse determinants in the context of entrepreneurial activities. In the case of India, these determining factors are more in number and pronounced. India being the materially disadvantaged economy is characterized by hierarchical social systems based on ethnicity, caste, gender, religion, economic and social status, and other factors; limited or non-existent welfare systems; subsidies eliminated as part of debt reduction programs; and a high level of unemployment. These features can be a stimulant to prospective entrepreneurs, though such entrepreneurs face characteristics uncertainty and risks due to political, social, and economic instability and lack of access to capital and institutional support (Leff 1979; Parwez 2016c).

This study tries to examine a community-based entrepreneurship through a case study approach with an implicit research question on how it can lead to livelihood development and eventual empowerment of the community at large. This paper is comprised of a conceptual and empirical analysis, with the application of a case study method in a communitybased retail chain for furthering of the concept, with the application of a case study method in a community-based retail chain with an aim of understanding the concept further.

\section{Methods}

Concerning the type of research applied in this form of study, a qualitative research approach is evidently dominant. New insights might be gained by applying a quantitative research approach more frequently. Although this study emphasis on qualitative research for the formulation of key concepts and operationalization; another important requirement is the availability of a requisite data, and it is rather problematic in general for the formulation of key concepts and operationalization, a second requirement is the availability of a requisite data, and this is still rather problematic in general. Expectedly, this study is based on primary data on the case. In addition, inquiries suffer from a uniformity of methods, and a case study design reigns.

This study follows a single-case design. The study has taken Friendly Mart as a case study to understand community-based entrepreneurship; events and activities are limited to a single occurrence. However, the drawback of a single-case design is its inability to provide a generalizing conclusion. To overcome this limitation, triangulation technique has been applied to confirm the validity of the process. By replicating the case through pattern-matching, a technique linking several pieces of information from the 
same case to some theoretical proposition has helped to raise the level of confidence in the robustness of the method.

The examination of the data is most often conducted within the context of its use (Yin 1984), that is, within the situation in which the activity takes place. To explore the strategies the reader uses, observing the subject within her environment provides great depth which isolates a phenomenon from its context, focusing on a limited number of variables. Second, variations in terms of intrinsic, instrumental, and collective approaches to case studies allow qualitative analyses of the data. Application of a case study relied on qualitative data which give descriptive accounts of the behavior of an individual, group, and enterprise. The detailed qualitative accounts not only are generally applicable to case studies to explore or describe the data in the real-life environment but also help to explain the complexities of real-life situations which may not be captured through experimental or survey-based data or research. A case study can give access to not only the numerical information concerning the strategies used but also the reasons for the strategy use, and how the strategies are used in relation to other strategies.

\section{Community-based entrepreneurship}

People, in general, are faced with issues related to poverty, illiteracy, lack of skills, poor health care systems, etc. These are problems that cannot be tackled individually but can be better solved through group efforts. There is a need to organize the poor and marginalized to come together for solving individual or collective problems (Yunus 2008). Communitybased entrepreneurship is now seen as a viable alternative for development processes.

A general model of a community-based entrepreneurship is the same across the region. It is led by an individual or a group, economically homogenous in nature. It has been recognized as an effective tool for capacity building of the marginalized section (Rao 2003). Several empirical pieces of evidence suggest that it does enhance the qualitative equality economic cultural spheres (McKiernan 2002; De, and Sarker 2010; Parwez 2014). The basic directive principles of community-based entrepreneurship are group approach, mutual trust, and motivation towards economic activities encouraged by institutional support. Suresh et al. (2003) summaries several factors associated with community-based entrepreneurship: functions like operations, internal problems, effective leadership, and support towards establishing a business venture.

Minniti and Bygrave (1999) argue that individuals' decisions towards entrepreneurship is influenced by "three simultaneous elements: (1) subjective initial endowment is personal, (2) institutional and economic circumstances of economy are community specific, and (3) the existing level of entrepreneurial activity in that community is perceived by the individual." The nature of these determinants suggests prevailing interventions some way or other addressing the issue or not. Bygrave and Minniti (2000) imply that determinant variation in entrepreneurship led processes from region to region, even with similar economic conditions. They conclude that there are threshold effects of entrepreneurship, and policy interventions that do not raise equilibrium in a community will not be successful.

The community-based entrepreneurship has evolved due to the efforts of committed individuals to promote self-employment. There is banking and non-banking, and national and international developmental agencies have also played a significant part in 
creating resources for these forms of activities. During the early 2000s, policy makers and agencies realized that it can be an effective developmental instrument.

The community-based entrepreneurial venture is facing problems in every step from societal barriers to the market. This form of entrepreneurship takes place among the marginalized group because of socio-economic constraints. Studies have shown that they can lift themselves from the morass of poverty and stagnation through entrepreneurial activities based on collective action (Suresh, and Saravan 2013).

The formation of a homogenous group with the purpose of furthering entrepreneurial activities is the challenge, directly or indirectly in the process of the empowerment (Asia and the Pacific Division, IFAD 2006). Further concentration can be towards the economic well-being, providing an opportunity for participation in the function of community-led economic activities (Kannabiran 2005).

The community-based entrepreneurship has given way to mobilization and empowerment of the poor, who can now manage their own well-being and be benefited from economic activities. The expansion of entrepreneurial activities is an important tactic for the overall strategy of economic development (Jonathan 2010). Community-based entrepreneurship is fairly simple; management is sustainable and their investment is on intensive entrepreneurial processes. The purpose is limited by unsatisfactory institutional support from finance to technical assistance and affects ability to fulfil basic requirement of entrepreneurial activities.

There is a certain limitation in institutional support programs; entrepreneurial activities create a possibility of safety or guaranty with respect to fulfilling their ambition. The support system is mainly concentrated to the bank network in India that too in limited extent (Satyasai 2003); hence, expecting a miraculous result without correcting the imbalances in the outreach is a mere illusion (Satyasai 2008). It is the need of the hour to formulate policies focusing on organizing people in a participative manner to be part of entrepreneurial activities rather than solely concentrating on unsustainable welfare schemes (World Bank 2003).

It is possible that several societal features of the poor or marginalized communities may serve as a barrier; entrepreneurship can take place in socially and culturally diverse settings (Dana 1995; Holt 1997). Economic crises and the adverse situation can also be a catalyst for entrepreneurial activity (Harper 1991). In challenging situations, there exists an array of reasons and only a few alternatives for an entrepreneur (Parwez 2014). The most compelling among these reasons is survival and the consequent need to recognize opportunities that will lead to desirable outcomes (Yusuf, and Schindehutte 2000).

A determining factor for enterprise development in these societies depends on the prevailing characteristics of the community. This characteristic leads to further understanding of entitlements of individual members in relation to the standing and legitimate requirements of the community itself (Peterson 1988). The more community-oriented a society is the more members will be entitled to certain societal benefits, including the satisfaction of needs connected with survival, such as basic income, healthcare, and safety.

It is essential to recognize, if that community orientation is inconsistent (Peterson 1988) then entrepreneurial accomplishment may not only be compatible with diverse social arrangements but may also benefit from the integration of specific cultural values and norms (Basu and Altinay 2002). Evidence suggest that a possibility of cultural 
identity may function as a tool for entrepreneurial activity. It appears that entrepreneurial activity can flourish in a diverse and dynamic societal and cultural environment. In many communities, especially in developing countries, a variety of combinations simultaneously creates space for a different economic logic to take place. Local public goods are mainly created by the community-led entrepreneurship rather than by the market public or private intervention (Parwez 2016a; Hayami 1997). This is because the community relationship prevents free riders.

Measuring the condition at a methodological level (case study) with respect to community-led entrepreneurship is a new form of entrepreneurial behavior (Dees and Ba le Anderson 2006; Dorado 2006; Short et al. 2009). Existing literature confirms that these are the early years of this concept. There are a good number of articles on community-based entrepreneurship both conceptual and empirical which are written in the last two decades; although, the absolute and relative number of empirical studies remains limited. It has been observed that agreement on the definitive concept is lacking; it is worth paying considerable attention to the explication of the concept with further research orientation.

\section{Community-oriented enterprise: a Friendly Mart case study}

Community-based enterprises use business to improve the life of a community in general. They are different from private enterprises; their business activity is undertaken as a means of achieving the benefit for the community, not for private gain. The key characteristic of community-based enterprises is that assets belong or dedicated to the community. It ensures that the enterprise is accountable to the community and that the profits or a surplus created are to be reinvested or distributed for the benefit of the community. However, for the sustainability of the enterprise, it needs to be profitable while serving the community.

Entrepreneurs such as Nazeer Khan of Friendly Mart and Ali Holdar's Qamar Restaurant are the perfect example of how a community-driven business can be successful while creating public goods for the community at large. Both these business enterprises belong to Chilea community. A business enterprise, supported by the community with community-oriented required support system, have potential to generate jobs, scale up, earn a profit, and return the benefit to the community beyond those directly employed personnel. They run an enterprise as a workerowned cooperative or a member-based association, as much of the human resource belongs to the Chilea community. There is a role for community-based social enterprises to help strengthen local economies.

Entrepreneurs such as Nazeer Khan and Ali Holdar are the reflection of a new form of a livelihood process as for the entrepreneur's minority community. Their success has been an inspiration to others. Generally, a large part of the minority population in India is stagnated to low-cost and low-paying jobs. Only when there is a scope that wealth generated can be used locally to improve the socio-economic condition of some or more in the community. Community-based social enterprises are unique as they organize business activities around the community in quest of providing direct benefit. They provide purposeful employment and cash income to the marginalized community members and add value as it stops cash to leak out to the non-community member. 
Supplying products for local consumption to the community to spin off more community enterprises leads to the development of economic decision-makers and actively engages citizens to the positive direction. Community enterprises involve stakeholders across the community; to the certain extent, the Chilea community has been successfully achieving by being brave and adventurous and by enterprising to set up an enterprise which is the reflection of change. But community-based enterprises are rare, mainly due to the low level of success and being confined to the only marginal community.

The above arguments are well supported by existing literature. In the last few decades, academics, politicians, and civil analysts have cited the falling level of community involvement, an issue for concern; community involvement has been fundamental to the process of development. Fyfe (2009) says that community engagement is the most important approach to addressing demographically and geographically emphasized programs. While many argue that engagement initiatives among communities are difficult to estimate empirically, some studies also reveal reviews of major regeneration development, demonstrating the importance of community engagement. It has been argued that despite the acceptance of community engagement, evidence does not support the prevalence of such engagement, which met mixed results. Furthermore, the critical analysis suggests that community engagement creates a sense of responsibilities for communities in terms of taking care of their surroundings (Lawson, and Kearns 2010). The literature around "community participation" is discussed in depth; the notion is that it is difficult to define in most accepted ways. The term is understood and spelt differently by numerous bodies as well as individual scholars, with some conflicting ideologies (Morris 2006). The benefits of community participation in a society are very extensive; some would say it is very comprehensive. Following decades of professional or state-led interventions, to be seen, the community has been an important knowledge resource, if captured, will lead to enhanced and responsible services. This aspect is based upon the simple base that the community knows best about their own problems, thus allowing policy makers to act according to that (Rydin, and Pennington 2000; Maguire, and Truscott 2006).

It has been observed that minority-owned firms hire minorities in high proportions. An unusual co-ethnic recruitment process by an ethnic minority's enterprises accompanied by new jobs leads to an increase of employment among minorities themselves. Co-ethnic employment processes stimulate self-employment, work flexibility, and furthering of socio-economic benefits within the community. Entrepreneurship provides an opportunity and an alternative to unemployment. In the current situation in a developing nation like India, entrepreneurship could be the right foot forward in tackling the evils of poverty.

Recent times, minority entrepreneurship has emerged as a contemporary area of interest among social scientist due to obvious reasons. There are both social and economic reasons that make minority's entrepreneurship important, considering unemployment and lack of formal education among minorities. Minority businesses are the essential part of the development of any society; personal initiative is encouraged and there is equal opportunity for citizens (Alvord et al. 2004). Considerable increases in minority-oriented business ownership can be an engine of economic growth, helping a good number of people. Minority business enterprises can make the economy stronger, facilitates community building and information flow, and enhances relationships. 
A notion of social entrepreneurship is the comparatively new initiatives that employ entrepreneurial capacity to resolve existing social troubles (Shaw and Robinson 2010). However, most writing in social entrepreneurship has tended to center on a prominent social entrepreneur's experiences, personal distinctiveness, leadership, and success factors (Alvord et al. 2004). There is inadequate literature about social entrepreneur's activities in terms of actions and outcomes. Most social entrepreneurship studies are not based on clear theoretical underpinnings (Mair and Martí 2006). Therefore, generalizability inhibits the existing social entrepreneurship studies, and we cannot develop consistent theorization of social entrepreneurship. Consequently, we contend that social entrepreneurship is more than individual characteristics; it is about their actions, and impact on society that should be studied using the clear theoretical framework. Social entrepreneurship is mainly viewed in literature as a social change which remotes social values and improves the well-being of people involved in the process of enterprising (Mair 2005).

Relevant for a case here, namely, Friendly Mart as a social enterprise in search of opportunities and devising ways to use capital eliminates constraints for a section of society. In a fragmented polity of a state like Gujarat, where social divisions of religion exist as an obvious limitation, overcoming and providing communal economic empowerment across geographical and class barrier in Chilea community (a Muslim sect), by sharing profit with the community, is deprived by existing political economy of the state.

The classical concept of broad-based development beyond the pockets of "upper classes" dates to the publications of Marx's volumes which elaborately deal "with classes." Socialist view of class doctrine fails to capture a secluded religious community's hopelessness. Even a socialist redistribution policy may not reach out to a religious minority group; policy biases towards minorities for empowerment could be helpful. In such market, imperfections of the non-Pareto efficiency of political economy in a community-oriented franchisee-based model of entrepreneurship seem to portray an innovative option and the possible path to inclusive development (Parwez 2016b).

\section{Setting up of Friendly Mart}

Nazeer Jafri is a cousin of Pir Syed Jafri (sect head of the Chilea community) from North Gujarat, who runs a network of approximately 100 restaurants in and around Ahmedabad along with restaurants in the highway of Ahmedabad to Mumbai. These restaurants are owned in a trusteeship form, having investment from several partners.

In 2002, when he was associated with the Grey Worldwide, he had an opportunity to visit Big Bazaar, located in the same building and was inspired by the ongoing activities; people were moving around and lifting things, putting it in the trolley and taking it to counter. He found the experience empowering for customers, different from the retail shops in Ahmedabad, and the people were shopping with smiling faces, enjoying the experience, and was also amazed by the grandeur of the mall. It led him to explore the idea of retail business further, also motivated by a subconscious desire to help the community. The belief that if any entrepreneur is ready to work hard, one can compete with big brands and can create one's own space in the market also took him further.

The restaurant was a business that could have been easier to start with due to the nature of his family background, but the restaurant business was cluttered in Gujarat; the 
restaurant business would be a run of the mill, not motivating enough. His ambition was to open a retail shop and grow it as a chain across the region. Retail sounded as a promising business as the market seems to be in a highly row (close to $4 \%$ organized retailing in India). It led to early discussions on the idea with peers for setting up a retail shop.

Nazeer discussed his ideas with Ali Bhai, with the proposal to set up a retail shop, who in turn told him to think big, maybe a supermarket. Additionally, he also advised Nazeer to communicate about the business plan in a social circle for investment. Otherwise, a loan from the banks can always be availed. Nazeer had Rs. 5 lakhs at his disposal from savings and could get Rs. 5 lakhs from close relatives to start the venture. But there was need of Rs. 40 Lakhs for setting up a supermarket of $700-1000 \mathrm{ft}^{2}$ area, which requires 20-25 lakhs for construction. After a meaningful discussion with his friends and family, he was flooded with offers for investment and, in fact, said no to some prospective investors.

The next major challenge was to identify the right location for setting up the shop; the following factors were crucial for the decision on the location: it should be in the neighborhood, the absence of an organized retailing, real estate should be reasonable, and the future developmental prospects of the area. Based on these considerations, the location of Vishala Circle (Ahmedabad) was zeroed-in for the first shop of Friendly Mart venture.

Other factors were comprised of the proximity to Vishala Restaurant, the mass number of households, the education level in the area, and the circulation of English and Gujarati newspapers. But the question whether locals will be able to appreciate retailing remained, targeting a customer base that is preferably from the middle and uppermiddle class in a predominantly Muslim neighborhood.

Locations such as Navrangpura, Khanpur, and Sarkhej were also considered for the purpose. The second best choice was Navrangpura, as it is a hub of the city and cosmopolitan culture; but it was already the hub to several organized retail shops, return on investment is far stretched, and real estate price was too high; and so, they decided against it.

Adani Super Market and others mushroomed all over Ahmedabad, so Nazeer saw opportunity in the old city. The third best choice was Khanpur, as it was the main area in the old city, which possesses a cosmopolitan area, an English medium school (Mount Carmel), clubs, hotels, a college (Bhavans), and a riverfront beautification project but the absence of an organized retail shop in the area; however, there was an issue of civil disturbances and the congested environment of that area. And, it was a cramped area so the real estate price was high and future development of the area was saturated.

The options that were left were Sarkhej or Vishala in Ahmedabad. As far as Sarkhej was concerned, the proximity of the area was the major issue, the household profile was not up-market, and locals may prefer the Kirana store to a supermarket. In the end, Vishala was chosen for the start of the venture. The major determining factors were as follows: relatively cheaper real estate prices, new residential schemes were being built, in the vicinity of the Vishala Restaurant, and the area emerged out of Juhapura (a Muslim Ghetto); so, future development prospects were bright. There was no organized retail outlet in the area, and people needed to be educated. The most threatening factor of the area was that Juhapura did not have the positive image among suppliers.

Because of the post communal riots (2001), Muslims from Navrangpura, Paldi, were moving to Juhapura in the sense of security, as lives were lost elsewhere in the city. 
The spot for the shop in Vishala circle was a vantage point as people returning from Paldi or Ashram Road or even from the industrial area of Narol could come and shop. The place was close to densely populated middle and upper-middle class Muslim community dwellings.

In hindsight, the success of the Friendly Mart in Vishala circle could be attributed to the ability of a young Muslim entrepreneur to understand the need of the people of a convenience store in the vicinity. Nazeer could easily enter the social spaces of the Juhapura and Sarkhej inmates due to the services offered in store, and his cultural status which ultimately yielded him success. Friendly Mart was gradually able to move into the personal spaces of customers and could create customer loyalty.

Vishala Circle has situated approximately $12 \mathrm{~km}$ from Ahmedabad airport and has been named after the theme restaurant Vishala Village, which provides traditional Gujarati cuisine in a village ambience. It is a major landmark in this part of the city. Vishala Circle offered a lot of promise, as the area was developing rapidly, and new residential schemes and various commercial complexes like Ellicon Tower and Sunrise Complex were coming up with good connectivity by roads.

Meanwhile, the following findings emerged from a dipstick survey by Nazeer: (i) Out of the 588 households in and around, 399 households were a ready customer base. (ii) The target business was to the tune of Rs. 30, 63,522. (iii) The potential business was worth Rs. 45, 14,664. This survey was conducted to find the household size, average monthly expenditure, purchase practices, and consumer behavior towards organized retailing. Nazeer contacted the builder of Ellicon Towers; there were six shops and ten floors owned by a close friend of Aljibhai, with enough parking spaces in a grand neighborhood. He decided to purchase two shops with a total of $700 \mathrm{ft}^{2}$, which was manageable in his budget in the complex.

Now, there was a need for a brand name, to create shop patronage. The brand name needed to be unique should be able to "connect" with the customers. To capture it, the brand was named as "Friendly Mart" with a baseline of "the friendly supermarket." The positioning needed to be long-lasting and unique, which depends on the customer's expectations and services offered. Due to the location of the store, it was a matter of access as people used to go to Vijay and Paldi; this was needed to be branded as the ideal neighborhood store. So, the positioning theme "SABSE KHAAS, GHAR KE PAAS" came to the table.

There was a need to create awareness of the shop, establish confidence among the suppliers, and build a friendly image among customers. To achieve it, he got guidance from a friend regarding the software to be used for computers, equipment to be bought, the layout of the interior in store, etc.

The store was to launch, and he employed a young man Anwar, who possessed experience in the field and lived nearby which provided him with the access to distributors. A week before the launch, orders were made to the distributors. $\mathrm{He}$ did commit some mistakes in the ordering process but it was a learning experience. The promotion started 10 days before the launch, he advertised through signage and the auto rickshaw with a loudspeaker, and inserts were distributed along with news sheets distributed in nearby colonies. On the launch day (12 February 2004) prominent people were invited, and he made a sale of Rs. 50,000/ less on day one. 


\section{Expansion into rural franchises}

A visit to Mundra Institute of Communication, Ahmedabad, gave him (Nazeer Khan) the idea of leveraging the business with a franchising structure across Gujarat. Expending in the locality where his credibility was in place made more business sense; it meant expanding into the north and central Gujarat, which possesses a sizeable population of the Chilea community. He discussed the idea with Sabir and Shabbir (managers of Ahmedabad Store) and assigned them to work on it, who later discuss the franchise model with the interested people in the village (north and central Gujarat). Two entrepreneur brothers Mehndi and Mahmud both farmers owning some land in Ilol volunteered to start off a franchise in April 2007.

The framework developed as the franchise would first register his company as a firm under the Companies Act. Technical and other support systems will be provided to them based on monthly fees on agreed terms and conditions. The benefit for the franchise was that if there were some issues to come up then later then the shop could become independent but need not be closed. The new shop at Ilol was registered as Friendly Mart Smart Shop Ilol. If there was an issue between the two parties Friendly Mart could move out of the agreement, and the franchise shall become Smart Shop Ilol.

The Friendly Mart Smart Shop in Talaav (Ilol) which was situated near a pond in the village and Pahaadiya (Ilol) was one and a half kilometers from Talaav on a slight elevation near a Kirana (convenience) store called Sahyog Kirana. Few store owners were keen to open a franchise seeing a good response to a smart shop but lack enough space, so, it may not pass muster as a Friendly Mart franchise. At time, the idea of a Saral store would be ideal to convert small Kirana stores into more organized shop, material organized in a systematic way, and sold across the counter. Thus, Friendly Mart Saral Sahyog Kirana Store came into being in October 2007. Then, a whole sequence of setting up stores in the villages' one after the other started.

\section{Distinctive features of Friendly Mart's business model}

Friendly Mart aimed to be the best in the locality in terms of perception and services offered; a convenience store which caters to the daily needs of people situated near, so, the target audience was the residents of the area. But now Friendly Mart has slowly spread its wings in different regions of Gujarat. Their franchises are operating in certain villages of Sabarkantha, and they wish to cover many more villages in the state.

In the organized retail industry, particularly the food retail, sales highly depend on the convenience of the customer. Evident by stories of big grocery stores like Subhiksha and Reliance Fresh, there is a wrong assumption that price is the deciding factor for any organized retail to be successful. In the Indian context, the housewife still bargains with the roadside vendor for her daily vegetables. The glamor of an organized retail has not made her change her purchasing habit of vegetables and fruits. Perhaps that is the reason many roadside vegetable vendors are in business near organized retail houses. A store which is conveniently located has much better chances of being successful than a store depending on promotional schemes, and convenience rules over pricing.

There are many product categories and brands which have been added and removed from the store over the last 5 years. He had launched a section called 20-20, every product was worth Rs. 20/less. Initially, he got a good response, but slowly, consumers 
turned away as the quality was a major issue, and the section was removed as it was hurting the Friendly Mart brand image.

He also tried a ready-made dress material section and a section for imitation jewelry, soon realized that huge space is required for these additional products with proper range and that having them in place is useless. It also created confusion among the clientele as Friendly Mart was perceived as a food and grocery convenience store and not a lifestyle store. Considering the continuous demand of sections on plastic products and crockery at Friendly Mart, these sections were later added. The customers received well both the sections; it also enhanced the image of the store.

Initially, when he launched Friendly Mart, his first purchase was based on speculation, conventional wisdom, and gut feel. There was no scientific way of understanding the right inventory mix and inventory size; an experience of running the store led to the realization of requisite inventory for the store.

Friendly Mart is the only organized retailer in Sarkhej-Juhapura road. This unique situation has many advantages and has a flip-side too. The distributors of products tend to have fixed their route and scheduling, which is once in a week or fortnight. As Friendly Mart is the new store, on the list of priority destination for distributors they fall downward; if for a certain reason they are out of stock of a brand, they must wait longer and may not get the emergency visit in between due to the low bargaining power. At times, certain merchandise which is not readily available at the store may disappoint customers. To solve this problem, Nazeer started ordering more quantity than the anticipated demand from the distributor and the second step was to purchase out of stock products from wholesale markets from areas like Kalupur if the distributor's visit is not expected in few days.

Does the characteristics of Friendly Mart differ considerably from those of the competition allows adequate differentiation? It is a typically organized food retail outlet, by that logic, it is like any other good retail outlet. Friendly Mart is in the process of expansion, and once his network is in place, planning to foray into private labels can then become key differentiators and provide advantages of economies of scale.

His subsidiary company Friendly Mart Enterprise caters to more than 150 highway hotels and 100 city-based hotels across Gujarat. He realized that he has access to a network of restaurants and if he is successful in creating a business around them in such a manner that it can be an asset to his retail venture. Then, he decided to foray into bulk hotel supplies of groceries and food item. It has also helped him earn negotiation and buying capacity of loose groceries, spices, and food items; and the benefits are transferred to the store and the franchises. He is also contemplating to develop ruralfocused products which can uplift the living standards of the villagers and can effectively cater their needs wide franchise network.

With more than 5 years of existence as an organized retail store in Juhapura, the goodwill of the business has enhanced and given an intangible growth. He also got the first mover advantage in this area and which again has contributed to the growth in brand value of the organization. When Friendly Mart was launched in Juhapura, in the year 2004, the area was still developing, and real estate prices were in the limit. Over the years, increasing residential schemes and apartments were established and the area has started gaining prominence. This has led to an increase in the real estate price, and investment in Friendly Mart outlet has grown 
manifolds. The prices of real estate have grown 4 times in 6 years, and this is a tangible part of his investment growth.

To leverage the business opportunity formation Friendly Mart Enterprise took place, a sister concern organization catering over 100 restaurants in and around Ahmedabad and 300 restaurants in other cities of Gujarat. For this purpose, Nazeer collaborated with two budding entrepreneurs Wazir Ali and Husain Abbas to look after the operational part of the business. Friendly Mart Enterprise was formed in 2008, and within the span of 2 years, turnover has gone up by $300 \%$ and profits have soared more than 4 times since then. Friendly Mart Enterprise is involved in developing private labels for supermarket business and hotel supplies.

Considering the huge demand of tea from his restaurant customers, although tea business is different from food-grocery, it led to the launching of a new subsidiary "Friendly Mart Tea Packers" with the brand name of "Day Break" in the year 2009-2010, which gave a launching pad to yet another budding entrepreneur (Abdul Basheer) in the community. The expertise of Friendly Mart in catering to hotels was a great help for Abdul. In the last year, Nazeer launched a new company "Friendly Mart (Surat) Enterprise" in Surat (financial capital of Gujarat) on the lines of Friendly Mart Enterprise, to cater to the local restaurants of the region. Local entrepreneurs and staff were trained at Friendly Mart Enterprise (Ahmedabad) for 1 year and then later sent to Surat to care of the venture.

To integrate the business even further, an off-shoot was introduced, namely "Friendly Mart Logistics" in the year 2009-2010; as the name suggests, it is a supply chain company for transport of merchandise from Friendly Mart Enterprise to franchise networks, hotels, and restaurants. Logistics arm also converted into the stockiest to other related product mixes like confectionery, biscuits, and food items, which can be provided to other distributors and retailers. Friendly Mart Logistics is run by an independent entrepreneur under Nazeer's guidance and supervision. To strengthen the backwards integration, another subsidiary was introduced, namely "Friendly Mart Farm Services," which mainly provides consultancy services (technical) to the farming community on the best farm practices to increase productivity and reduce production cost. In return, Friendly Mart Enterprise would purchase the produce as per the market rate and would benefit the farmers and the enterprise mutually. If the produce is more than Friendly Mart Enterprise would market the same, farmer may end up earning better returns.

Nazeer's purpose is to help the entrepreneurs with their franchise business as the growth of the franchise network and the subsidiary will reflect on the growth of the overall business.

\section{Results and discussion}

This paper is a preliminary effort to elucidate the concept of community-based entrepreneurial activities based on evidences from a case. It tried to identify the determinants leading to formation, composition, operation, and offering of community-based entrepreneurship as a means of economic or livelihood development. There is obviously a considerable scope of further research which remains as conjectures offered in origins, evolution, and collateral effects of the said phenomenon to increase our comprehension connected with the construction, progression, and performance of under-recognized (or unrecognized) form of enterprising processes. 
Major determinants could be shared locality or values (e.g., "kin-based" and various forms of voluntary as well as "natural" associations as evident in Chilea community). Factors such as rural, urban, indigenous reserves, and new settlements are also could be an impacting one. Juhapura locality happens to be the new settlement for a Muslim community after the communal riots in 2001, in another word a Muslim ghetto. Deprived socio-economic status of Muslims can be considered as a key determinant of entrepreneurial activity as observed in the case. The study also suggests that entrepreneurship among a Muslim community characteristically emerge in an environment of economic stress, drawing from the community's traditions of helping each other. The question could be the extent to which community-based economic activities may be an effective instrument in the context of developing the livelihood that can be replicated in communities that may or may not have a shared a characteristic.

The likely impact of community-oriented enterprises towards sustainable benefits of marginal communities helps in better understanding of a new form of entrepreneurial activity but limited by scarcity of literature. In case of Friendly Mart, benefits are limited to few people involved in the related commercial activities irrespective of place, language, religion, or community. So, spillover effects are absent or limited in nature (Peredo, and Chrisman 2006). There are many aspects of community-based entrepreneurship which require both qualitative and quantitative assessment for furthering the knowledge.

Community-based enterprise offers a promising approach towards poverty reduction in deprived communities to the limited extent. However, economic and non-economic goals can enhance the realization of social and material resources of the communities as suggested by the case. It also touches upon the role of cultural values, institutional arrangements, and structures in the formation of the enterprise. Study emphasis on the management skills is required in a day-to-day decision-making while keeping the consistency with the broader goal as a commercial entity.

The close coupling between capitals and capacity, resource tenure, and informed leadership can work as an analytical framework for furthering the research. The challenge is the interaction between the local regulatory framework based on one's institutional values and norms with the national and international frameworks built on different logic. Although it can be noted, this is an ongoing process.

Finally, as reflected in this paper, leadership is the most critical element for the success of community-based enterprises (Anderson et al. 2006). In the early days of communitybased entrepreneurship, leadership is the most crucial factor to recognize opportunities and risks while mobilizing capitals and capacities to realize social benefits.

The case study also reflects that asymmetry of the information creates a moral hazard in the community. Personal interactions among people play a vital role in avoiding moral hazard. In other words, community-based entrepreneurship can be considered as a window of opportunity to realize potential, otherwise remained isolated from the mainstream economy. This is important as to bring social upliftment of a community.

It can be stated that access to capital to mainstream connections can be a determining factor towards entrepreneurial success or failure. Community-based activities lead to dependence on sect partners, personnel, and customers which can be limiting in nature. This form of entrepreneurship is also plagued with communal cultural limitations about business ethos, lack of managerial experience, formal business training, and familiarity with the institutional and legal environment. The capital concentration of 
enterprises in urban ghettos and societal hostility are few of the principal challenges faced by ethnic entrepreneurs in Muslim communities are prone to. Many selfemployed Muslim workers and small business in urban centers in a non-Islamic society indicate that they are bound to have a great propensity for entrepreneurial activities.

\section{Conclusions}

This study tries to emphasize on the development of a comprehensive approach towards community-based enterprising to enhance livelihood prospects for local population. It is evident that entrepreneurial ventures are motivated by community orientation and undertaken with the expectation of profits to be used for an expansion and the empowerment of members. But it remains to be established as an effective model for achieving community goals, as current evidences are limited in nature. Reflections from the study suggest that community affiliation combined with requisite entrepreneurial skills is essential for this form of enterprising to be successful. A community-based entrepreneurship should reflect on the multiplicity of local needs; however, this factor is missing in this case which needs to be explored further. The empowerment promoted by community enterprises suggests a shift towards the strengthening of existing capacities at an individual level and groups in a community. The major limitation of this phenomenon is the lack of community orientation in a modern society, capacity, and generalization of a model elsewhere. Community-based entrepreneurial activities could be an effective response to the "structural and functional disconnection between indigenous, informal, and formal institutions." Few policy initiatives need to be taken for fostering a positive attitude towards entrepreneurship among members of weak communities and encouraging the catalytic role towards further development.

\section{Acknowledgements}

I am grateful to the reviewers of the journal for their extremely useful comments and suggestions. This paper has been prepared in good faith based on the information available at the date of publication.

\section{Competing interests}

The author declares that he has no competing interest.

\section{Publisher's Note}

Springer Nature remains neutral with regard to jurisdictional claims in published maps and institutional affiliations.

Received: 20 January 2017 Accepted: 7 June 2017

Published online: 11 July 2017

References

Alvord, S. H., Brown, L. D., \& Letts, C. W. (2004). Entrepreneurship and societal transformation: an exploratory study. The Journal of Applied Behavioral Science, 40(30), 260-282.

Anderson, A. R., \& Jack, S. L. (2002). The articulation of social capital in entrepreneurial networks: a glue or lubricant? Entrepreneurship and Regional Development, 14, 193-210.

Anderson, R. B., Honig, B., \& Peredo, A. M. (2006). Communities in the new economy: where social entrepreneurship and Indigenous entrepreneurship meet. In C. Steyaertt \& D. Hjorth (Eds.), Entrepreneurship as Social Change. Cheltenham: Edward Elgar.

Asia and the Pacific Division, IFAD. (2006). Indigenous people and ethnic minorities (p. 10). Philippines: International Fund for Agricultural Development.

Basu, A., \& Altinay, E. (2002). The interaction between culture and entrepreneurship in London's immigrant businesses. International Small Business Journal, 20(4), 371-393.

Bates, T. (1997). Financing small business creation: the case of Chinese and Korean immigrant entrepreneur. Journal of Business Venturing, 12, 109-124.

Brinkerhoff, D. W. (1996). Perspectives on participation in economic policy reform in Africa. Studies in Comparative International Development, 31(3), 123-151.

Burkey, S. (1993). People first: a guide to self-reliant participatory rural development. London; Atlantic Highlands, N.J: Zed Books.

Bygrave, W., \& Minniti, M. (2000). The social dynamics of entrepreneurship. Entrepreneurship Theory and Practice, 24(3), 25-36. 
Cornwall, J. R. (1998). The entrepreneur as a building block for community. Journal of Developmental Entrepreneurship, 3, $141-148$.

Crewe, E., \& Harrison, E. (1998). Whose development? An ethnography of aid. London; New York: Zed Books.

Dana, L. P. (1995). Entrepreneurship in a remote sub-Arctic community. Entrepreneurship Theory and Practice, 20(1), 57-73.

Davis, S. (Ed.). (1993). Indigenous views of land and the environment. Washington, DC: The World Bank.

De, S., \& Sarker, D. (2010). Impact of Micro-credit Programmes on Women Empowerment: An Empirical Study in West Bengal. The Microfinance Review, 2(1), 46-67.

Dees, J. G., \& Ba le Anderson, B. (2006). Framing a theory of entrepreneurship: building on two schools of peace and thought. ARNOVA Occasional Paper Series: Research on Social Entrepreneurship: Understanding and Contributing to an Emerging Field, 1(3), 39-66.

Dorado, S. (2006). Social entrepreneurial ventures: different values so different process of creation. Journal of Developmental Entrepreneurship, 11(4), 319-343.

Drucker, P. F. (1995). Managing in a time of great change. New York: Truman Talley Books/Dutton.

Fyfe, A. (2009). Tackling multiple deprivation in communities: considering the evidence. ODS Consulting, Scottish Government.

Harper, M. (1991). Enterprise development in poorer nations, entrepreneurship theory and practice, 15(4): 7-12.

Hayami, Y. (1997). From the Poverty to the Wealth of Nations, Development Economics. Oxford: Clarendon Press.

Hofstede, G. H. (1980). Cultural consequences: international differences in work-related values. Thousand Oaks, CA: Sage publications.

Holt, D. H. (1997). A comparative study of values among Chinese and US entrepreneurs: pragmatic convergence between contrasting cultures. Journal of Business Venturing, 12, 483-506.

Jonathan, J. M. (2010). The Microfinance Schism. In D. Hulme \& T. Arun (Eds.), Microfinance: A Reader. London and New York: Routledge.

Kannabiran, V. (2005). Marketing Self-Help, Managing Poverty. Economic and Political Weekly, 20, 3716-3719.

Lawson, L., \& Kearns, A. (2010). Community engagement in regeneration: are we getting the point? Journal of Housing and the Built Environment, 25, 19-36.

Leff, N. H. (1979). Entrepreneurship and economic development: the problem revisited. Journal of Economic Literature, $17(1), 46-64$.

Maguire, K., \& Truscott, F. (2006). Active governance: the value added by community involvement in governance through local strategic partnerships. United Kingdom: Joseph Rowntree Foundation.

Mair, J. (2005). Social entrepreneurship creating economic and social value, University of Navarra-IESE Business School Working Papers Series.

Mair, J., \& Martí, I. (2006). Social entrepreneurship research: a source of explanation, prediction, and delight. Journal of World Business, 41(1), 36-44.

McKiernan, S. (2002). The impact of micro credit programs on self-employment profits: do non credit program aspects matter? The Review of Economics and Statistics, 84(1), 93-115.

Minniti, M., \& Bygrave, W. (1999). The microfoundations of entrepreneurship. Entrepreneurship Theory and Practice, 23(4), 41-52.

Morris, J. (2006). Removing the barriers to community participation. National Community Forum.

Parwez, S. (2015). Microfinance for socio-economic development: an empirical analysis of NABARD initiative, GNLU Journal of Law, Development and Politics, Gandhinagar: Gujarat National Law University, 5(1): 21-38.

Parwez, S. (2016)a. A comparative study of Gujarat and Kerala developmental experiences, International Journal of Rural Management, Sage Publications, 12(2), 104-124.

Parwez, S. (2016)b. A study on Special Economic Zone implicated land acquisition and utilisation, International Journal of Development and Conflict, Gokhle Institute of Politics and Economics: Pune, 6(2), 136-153.

Parwez, S. (2016)c. A conceptual model for integration of Indian food supply chains, Global Business Review, Sage Publications. 17(4), 834-850.

Parwez, S. (2014). Impact assessment of self help group towards rural development: a case study of Jharkhand, India. Sahulat: A Journal of Interest Free Microfinance, 2(1), 83-94.

Peredo, A. M., \& Chrisman, J. J. (2006). Toward a theory of community-based enterprise. Academy of Management Review, 31(2), 309-328.

Peterson, R. (1988). Understanding and encouraging entrepreneurship internationally. Journal of Small Business Management, 26(2), 1-8.

Rao, V. M. (2003). Women Self Help Groups, Profiles from Andhra Pradesh and Karnataka, Kurukshetra, 50(6), 26-32.

Rydin, Y., \& Pennington, M. (2000). Public participation and local environmental planning: the collective action problem and the potential of social capital. Local Environment, 5, 153-169.

Sachs, W. (1992). The Development dictionary: a guide to knowledge as power. London; Atlantic Highlands, NJ: Zed Books.

Satyasai, K. J. S. (2003). Microfinance in India: Progress and Perspectives, Institutional Change in Indian Agriculture, 305.

Satyasai, K. J. S. (2008). Rural credit delivery in India: structural constraints and some corrective measures, Agricultural Economics Research Review, 21.

Schumpeter, J.A. (1983). The theory of economic development: an inquiry into profits, capital, credit, interest, and the business cycle (R. Opie, Trans.). New Brunswick, N.J.: Transaction Books. Original publication: 1934

Schumpeter, J. A. (1934). The Theory of Economic Development (pp. 23-49). Cambridge: Harvard University Press.

Shaw, K., \& Robinson, F. (2010). UK urban regeneration policies in the early twenty-first century: continuity or change? Town Planning Review, 81, 123-149.

Short, J. C., Moss, T. W., \& Lumpkin, G. T. (2009). Research in social entrepreneurship: past contributions and future opportunities. Strategic Entrepreneurship Journal, 3(2), 161-194.

Suresh, R. (2003). Entrepreneurial behaviour of milk producers in Chittoor district of Andhra Pradesh-A critical study (pp. 33-129). Hyderabad: Acharya N. G. Ranga Agricultural University.

Suresh, S. S., \& Saravan, S. (2013). Women Empowerment through Self Help Groups: A Case Study. Economic Affairs, 58(2), 147-154. 
World Bank (2003). Scaling Up Access to Finance: On the Critical Path to the MDGs: The Roles of Governments, Donors and the Private Sector, Washington, D.C.

World Bank. (1996). World Bank participation sourcebook. Washington: World Bank.

Yin, R. K. (1984). Case Study Research: Design and Methods (pp. 27-59). Beverly Hills, Calif: Sage Publications.

Yunus, M. (2008). Grameen bank at a glance, Bangladesh: Grameen Bank, 12-17. Retrieved on March 27th, 2015, from http://www.grameeninfo.org/bank/GB Glance.htm

Yusuf, A., \& Schindehutte, M. (2000). Exploring entrepreneurship in a declining economy. Journal of Developmental Entrepreneurship, 5(1), 41-57.

Submit your manuscript to a SpringerOpen ${ }^{\circ}$ journal and benefit from:

- Convenient online submission

- Rigorous peer review

Open access: articles freely available online

High visibility within the field

Retaining the copyright to your article

Submit your next manuscript at $\gg$ springeropen.com 